\title{
The Government and Mainstreaming Religious Education: Religious Moderation in the Reconfiguration of The Ministry of Religious Affairs and the Religious Organization in Jambi Province, Indonesia
}

\author{
$1^{\text {st }}$ Bahrul Ulum ${ }^{1}, 2^{\text {nd }}$ Mufdil Tuhri ${ }^{2}$ \\ \{bahrululum@uinjambi.ac.id ${ }^{1}$, mtuhri@uinjambi.ac.id² \\ UIN Sulthan Thaha Saifuddin Jambi ${ }^{1,2}$
}

\begin{abstract}
This paper focuses on the implementation of policies on the significance of religious moderation on education organized by The Ministry of Religious Affairs and religious organizations which affects different educational institutions of religious communities that exist throughout Jambi Province. We selected four religions respectively, Islam, Christianity, Buddhism, and Confucianism that have educational institutions affiliated at the school level or university. Based on ethnographic-based fieldwork, this research will explore how the state's ideology and discourse are implemented in the religious moderation project to build fairness, patriotism, tolerance, non-violence, and inclusive attitudes towards local traditions. The research will also examine the extent to which the attempts by the religious organization influence the policies of religious moderation on education, which then accommodate the local context of Jambi in particular and Malay tradition in general. Finally, this study proposes the reconsideration of the role of the politics of education in sustaining religious networks in the local context.
\end{abstract}

Keywords: Religious moderation, religious organization, state, Indonesia.

\section{Introduction}

One of the most important paradigms in the current administration of President Joko Widodo is Religious Moderation which has been included in the National Medium-Term Development Plan (RPJMN) for 2020-2024. This was followed up by a regulation in the form of a Circular Letter of the Director-General of Islamic Education (Number B3663.1/Dj.I/BA.02/10/2019 dated October 29, 2019, concerning Religious Moderation Houses), which requested all Chancellors of State Islamic Religious Universities ( PTKIN) to establish and organize houses of Religious Moderation as a space for seeding, educating, mentoring, and strengthening the religious moderation movement in the campus environment. Religious Moderation as a current government project was born during the leadership of the Minister of Religion Lukman Hakim Saifuddin under President Joko Widodo. The consequences of religious moderation are part of the 2020-2021 RPJMN which has consequences where every ministry and institution should socialize and make this program a success. Religious moderation 
makes the Ministry of Religion the only official institution that becomes the leading sector in charge of overseeing the implementation of this policy.

There is a lot of literature that has discussed the topic of religious moderation. Among the studies on religious moderation are many related to the concept of religious moderation in several Islamic organizations. Darajat proved that moderate Indonesian Islamic organizations such as NU and Muhammadiyah have the potential to counteract the rise of radical movements that have developed in Indonesia in recent years[1]. Hilmy reaffirmed the color of Indonesian Islam as moderate Islam as represented by NU and Muhammadiyah. The characteristics of Islamic moderation in Indonesia can be an ideal solution and strategy in dispelling the symptoms of increasing radicalism in the Islamic world today must be able Several other studies examine the implementation of religious moderation policies carried out in educational institutions [2]. Syatar provides an overview of the importance of realizing religious moderation in Islamic universities because of the increasing radicalism and religious extremism in the world of education [3].

In contrast to previous studies, we try to explain the practice of religious moderation in the aspect of religious education in the configuration of the Ministry of Religion and religious organizations. Substantially, religious moderation as understood in this article is moderation in the aspect of appreciation and understanding of religion. This underlies a thesis that religion is moderate or in terms of this it is not meant as religious moderation. Consequently, these religious groups have had the concept of religious moderation. At the same time, this view on religious moderation will be seen concerning the concept of religious moderation promoted by the government, in this case, the Ministry of Religion. This study does not intend to provide a conceptual classification of the meaning of religious moderation in religions in Indonesia, but this study intends to provide a sociological and historical description of religious moderation and the configuration of the state and religious organizations in Indonesia.

The state and mainstreaming of religious moderation presented in this article can be understood as a construction of religious moderation by the Ministry of Religion as the government and its relationship with non-governmental agencies, namely religious organizations. When looking at the relationship between these two structures, the focus will be on the conceptual and practical aspects of religious organizations. Conceptually, religious moderation will be viewed qualitatively based on library research and interviews. Given the limited access during Covid-19 to obtain data related to adequate interviews with religious leaders, we took the initiative to present data obtained from online media. This is also based on the context of religious moderation as a new term in the discourse of the ministry of religion in particular and the politics of religion in Indonesia. Thus, several studies of speeches, seminars, and dialogues delivered in the media can be an important contribution to the portrait of today's discussion of religious moderation. Furthermore, this data is expected to provide insight into the discourse of religious moderation that develops not only at the level of everyday social reality but also in the media realm. This is done to obtain the concept of the meaning of religious moderation in the 3 religions studied, namely Islam (Nahdlatul Ulama and Muhammadiyah), Christianity, and Buddhism. Next, we will examine the influence of the state and religious organizations at the central level on the implementation of religious moderation policies in Jambi province. This study aims to explain the meaning of religious moderation among interfaith groups in Jambi Province. This study hopes to provide a discussion on the concept of religious moderation which is understood and interpreted locally by religious organizations in Jambi Province. This study questions whether religious organizations at the local level of Jambi province have adequate knowledge of religious moderation as proposed by the Ministry of Religion? How do religious organizations respond to the government's project of religious 
moderation? Is there a significant influence of religious organizations at the central level on the implementation of mainstreaming religious moderation in the regions? To what extent are religious organizations able to translate religious moderation policies that have been included in the RPJMN in the realm of education and other organizational activities?

\section{Methodology}

In this research, we selected four religions respectively, Islam, Christianity, Buddhism, and Confucianism that have educational institutions affiliated at the school level or university. Within Islam, we selected two religious organizations including Nahdlatul Ulama and Muhammadiyah representing the dominant group in the area. For each organization, we selected one university and two secondary schools. Within Christianity, we selected one university and two secondary schools. Due to the lack of religious-affiliated universities, for Buddhism and Confucianism, we only selected two secondary schools. Based on ethnographic-based fieldwork, this research will explore how the state's ideology and discourse are implemented in the religious moderation project to build fairness, patriotism, tolerance, non-violence, and inclusive attitudes towards local traditions.

\section{Result and Discussion}

\subsection{The concept of religious moderation among religious organizations}

The word moderate is linguistically derived from the Latin, namely moderation which means justice (not "over" and not "lacking"). Religious moderation is different from religious moderation. Religious moderation may include Islamic moderation, Christian moderation, Buddhist moderation, Hindu moderation, Confucian moderation, and moderation of other religions. Many studies that use the term religious moderation explicitly and implicitly have explained the normative concept of religion about the doctrinal and normative aspects of religion which is referred to as moderate. However, the praxis of religious moderation is not easy to identify and categorize. If this question is asked of a particular religious group, then all are moderates as they would claim. Instead of looking at religion, whether religion is moderate, religious moderation can be seen as moderation in religious practices and religious ideas that are shared by groups that have one goal and origin rooted in the awareness of human needs [4].

There are various views on Religious Moderation by religious groups. In Islam, two major organizations, namely Nahdlatul Ulama and Muhammadiyah, have the concept of religious moderation as the driving force for their organization. The concept of Religious Moderation in Nahdatul Ulama has roots that can be referred to since the early days of the organization's founding. This can be traced in two essays by Achmad Siddiq, namely Khittah Nahdliyyah which was first published in 1979, and Islam, Pancasila, and Ukhuwah Islamiyyah (1985). Siddiq mentions that there are three characteristics of Sunni Islam that are understood by Nahdatul Ulama, namely: al-tawaasut (moderate), al-I'tida (justice), and al-tawazun (balance). In some ways, this also includes one characteristic, namely al-tasamu (tolerance) [5]. Theologically, according to Siddiq, the principle of moderation is manifested in the form of a balanced combination of reason and revelation and between purification of religion from heresy and tolerance for syncretic beliefs. In Sufism and ethics, the principle of religious moderation 
is a balance between excess (al-ghuluw) and immoderation or extremism (al-tatarruf). In terms of culture and tradition, the doctrine in NU known as al-muhafaza ala al-qadim al-salih wa alakhdhu bi al-jadid al asla (Preserving the good aspects of the old and adopting the better ones of the new) is the real form of conceptualization of the principles of al-tawasut, al-I'tidal and al-tawazun [5].

Meanwhile, the concept of Islamic moderation in Muhammadiyah can be seen in Haedar Nashir's 2015 book entitled "memahami Ideologi Muhamadiyah" [6]. According to Nashir, the Muhammadiyah Islamic movement from the beginning has developed an Islamic moderation with a view of progress as embodied in the view of progressive Islam (Islam as Din alHadlarah) [7]. Nasir said that the progressive Islamic ideology is clear evidence of Muhammadiyah's commitment to display an Islamic style that combines purification with dynamics and is moderate in believing and understanding and implementing Islamic teachings. Among the views of progressive Islam according to Muhammadiyah is "Progressive Islam sows the seeds of truth, goodness, peace, justice, benefit, prosperity, and the virtue of dynamic life for all mankind. Islam upholds the dignity of human beings, both men and women without discrimination. Islam promotes anti-war, anti-terrorism, anti-violence, anti-oppression, antibackward missions, and is anti-all forms of destruction on earth such as corruption, abuse of power, crimes against humanity, exploitation of nature, and various evils that destroy life. Islam positively gives birth to virtues that underlie the diversity of ethnic groups, races, groups, and cultures of mankind on earth [8]." Furthermore, in the attachment to the decision of the 46th Muhammadiyah Congress regarding the revitalization of Muhammadiyah education, the vision of Muhammadiyah education is stated, namely "the formation of human learners who are pious, have a noble character, and are advanced and excel in science and technology as the embodiment of tajdid da'wah amar ma'ruf nahi munkar."

The conception of Islamic moderation in the two Islamic organizations above shows the characteristics of Indonesian Islam. Azyumardi Azra calls this term the orthodoxy of Islam Nusantara which is characterized by accommodating, tolerant, relaxed and flowery. Azra views the moderation model of Islam in Indonesia as leading to Islam which has the characteristics of the Shafiiyyah style of Islamic law school, the al-Ghazali style of Sufism, and the Asyariyyah and maturidiyyah style of theology [9]. In the political field, the moderate attitude of Muhammadiyah and NU appears to be NU's political decision-making that prioritizes wisdom. However, the principle of religious moderation appears at point 6 in the basic values of Muhammadiyah education, namely paying attention to and implementing the principle of balance (tawassut or moderation) in managing educational institutions between common sense and purity of heart. This proves that since 2010, moderation has become a concept of Muhammadiyah education [10].

In its development, this conception of Islamic moderation changed meaning after the events of September 11th. The application of Islamic moderation no longer emphasizes inter-religious relations, be it theological differences, Sufism, and legal orientations in Islam, but refers to the Islamic dichotomy of liberal and radical groups [5]. In 2003, an international conference with the theme of da'wah strategy towards the Wasathon community in the face of radicalism was held by the Tabligh Assembly and Da'wah Muhamamdiyah in collaboration with the NU da'wah institution. This conference inspired the birth of the Center for Moderate Moslem (CMM) led by Muhammadiyah and NU. At that time the birth of this study center was a response to the anxiety of these two organizations against the rise of Islamic movements that were considered extreme, both extreme right and extreme left. In this case, the extreme right movement is represented by the Radical Islam movement while the extreme left movement is represented by the Liberal Islam group [11]. 
If conceptually NU and Muhammadiyah have a basis for religious moderation, then how far this concept is implemented in the empirical realm of this organization, both at the cultural level of society and structurally institutionally. To see this development, we can refer to the contemporary efforts of these two organizations in fighting for Islamic values which are characterized by Indonesianness. The idea of Islamic praxis in Muhammadiyah and NU is often seen as part of the contestation and competition between Muhammadiyah and NU. Muhammadiyah carries the idea of progressive Islam and Nahdlatul Ulama with the idea of Nusantara Islam. The attitude of Muhammadiyah and NU emerged in response to the symptoms of radicalism and intolerance that developed in Muslim society in Indonesia. Azyumardi Azra views that there is a religious reconfiguration that carries the middle way ideology, namely Wasatiyah Islam [12].

If you look at the conception of religious moderation in religion above, it seems that religious moderation is not a new theme. Each religious organization already has an adequate formulation of religious moderation. In the view of the Minister of Religion, Lukman Hakim Saifuddin in the Book of Religious Moderation, he stated: "Religious moderation is not a new thing for our nation. Indonesian society has deep-rooted social and cultural capital. We are used to tolerance, tolerance, respect for brotherhood, and respect for diversity. It can be said, such fundamental values are the foundation and philosophy of the people in the archipelago in undergoing religious moderation. This value exists in all religions because all religions teach the same human values" [13]. This shows that the concept of religious moderation has no major differences from one another. The use of the term religious moderation was deliberately chosen instead of using the term religious moderation.

\subsection{Religious moderation in The Ministry of Religion: a discourse}

In 2014, the government of Joko Widodo had voiced the aspiration of religious moderation but it had not become a priority program. At the end of the period of Joko Widodo's administration, in 2018, the High-Level Consultation (KTT) of the World Muslim Ulemas took place. In this forum, 12 characters of Islamic Moderation were agreed upon. This summit was successfully held thanks to the role of Muhammadiyah figure Din Syamsuddin who became the government's special envoy for religious affairs. At the level of ideas, the conceptualization of Religious Moderation emerged in the following years, precisely during the leadership of the Minister of Religion Lukman Hakim Saifuddin in the era of President Joko Widodo. Minister Lukman Hakim Saifuddin is a minister who previously served under President Susilo Bambang Yudhoyono. In its time, the diction of religious moderation became a new paradigm promoted by the Ministry of Religion which was previously known in various other terms such as Islamic moderation, Wasatiyah Islam, or Moderate Islam.

Religious moderation as a government project which has recently shown its strong influence in society can be seen in the last few decades. It seems that the emergence of several new groups within the body of Islam is related to the development of Islam after the reformation. Many observers say that the reform era marked the birth of new Muslim groups that had not existed before. In observer terms, this phenomenon is referred to as or "conservative turn" [14]. or "the end of innocence" [15]. This is different from the face of Islam before the reformation, especially during the era of President Soeharto or the New Order era which featured Islam with a smiling face. However, the development of Islam at this time was often marked by the silence and restriction of various religious activities. The Lindsey team (2020) considers that the new order under Suharto's image tends to display Islam with a dominant, modernist face. The Suharto era emphasized the stability and security of the nation. The discourse that is developing 
is a secular state that is moving towards modernity. The politics of managing diversity at that time was aimed at creating a conducive political climate in realizing national development.

In the post-Soeharto era, symptoms of increasing intolerance, extremism, and theorizing emerged. A condition that has not or rarely appeared in previous public discussions. The postSoeharto era was marked by the increased expression of Islam in the public sphere. The postSoeharto government is often faced with case pressure from Islamist groups. The emergence of new Islamic organizations such as Hizb ut-Tahrir Indonesia, the Islamic Defenders Front, the Indonesian Mujahideen Council is among the organizations that are often in a conservative or Islamist position. Against the emergence of this group, some people regard them as a threat to the pluralist group. Although, for the most part, this group supports religious piety and rejects violence rooted in intolerance.

In 2020, The center for the study of Islam and Society (PPIM) research shows that there are indicators of decreasing religious intolerance in several campuses in Indonesia. This is realized in several Islamic campuses that feel anxious when Islamism thrives, such as through the activities of the LDK (Campus Da'wah Institution), the tarbiyah movement, Hizbut Tahrir Indonesia. These 3 groups are considered by many to be a fact that even within Islamic campuses, the Islamism movement can develop and even shift groups such as the Islamic Student Association (HMI), the Indonesian Muslim Student Movement (PMII) which are often considered moderate group. Ropi sees that the opposition faced by the government encourages the management of religion to create a harmonious life. The state of Indonesia has a serious experience of division and social cohesion after the reform era. Indications of increasing religious intolerance and the emergence of organizations that carry ideologies that are different from the mainstream can threaten the integration of the nation [4].

The background above shows that serious challenges are being faced by the government. In 2014, Minister Lukman Hakim Saifuddin formulated an agenda for religious moderation by forming a team to formulate a book entitled Religious Moderation which was compiled by the Religious Moderation Task Force of the Ministry of Religion under the coordinator Oman Fathurrahman who is an expert staff of the Ministry of Religion. This book was launched at UIN Jakarta by the Center for the Study of Religion and Culture (CSRC). On the occasion of the launch of this book, Oman said that the religious moderation book was an initial effort in realizing the implementation of religious moderation in all work units of the ministry of religion and related institutions such as Islamic universities. According to Oman, the implementation stage of religious moderation aims so that this idea can become a perspective in religious and national life. At the same time, it is also hoped that it can change ideas or paradigms that are considered problematic today, namely religious extremism. In his book, religious moderation is a form of rejection of religious radicalism. According to the Rector of UIN Jakarta, Amany Lubis, since the launch of religious moderation at the national meeting of the ministry of religion, UIN Jakarta has welcomed this idea by making religious moderation the theme of UIN Jakarta's anniversary in 2020. UIN Jakarta has also established the house of religious moderation (rumah moderasi).

In the context of the ministry of religion, the declaration of religious moderation has already begun at the National Working Meeting of the Ministry of Religion. Since then, in our observations, almost all work units within the Ministry of Religion have scheduled Religious Moderation as their central theme in various fields such as religious education, religious education, and other sectors. Based on data obtained from the website of the ministry of religion, there is a special rubric with the theme of religious moderation, which includes reporting on the development of the discourse on religious moderation in the Ministry of Religion [16]. Even today, during the new government of the Indonesian Ministry of Religion under the leadership 
of Yaqut Cholis Chaumas, strengthening religious moderation has become a priority. Yaqut said that there are five steps in strengthening religious moderation, namely 1) strengthening the perspective, attitude, and practice of middle way religion. 2) strengthening the strengthening of the harmonization and harmony of religious communities. (3) alignment of religious and cultural relations. (4) improving the quality of religious life services. (5) economic development and religious resources [16].

In its further development, religious moderation as the main principle of national development has been stated in the 2020-2024 RPJMN by the National Development Planning Agency (BAPPENAS RI). There are five priority programs in the 2020-2024 RPJMN, namely the first is to strengthen the perspective, attitude, and practice of religious moderation; the second is to strengthen religious harmony and harmony; the third is to strengthen the relationship between religion and culture; fifth is to improve the quality of services for religious people; fifth is to develop the economic capacity and resources of religious communities. This shows that the values of religious moderation must be internalized and become the spiritual, moral, and ethical foundation in the landscape of the nation and state.

The current paradigm of religious moderation can be a form of state instrument to manage diversity. The Director-General of Islamic Education at the Ministry of Religion emphasized that religious moderation is a concept offered by the government in realizing religious tolerance which is carried out through a communication process. This proves that the religious moderation project is one of the new mechanisms offered by the government in managing diversity and religion in Indonesia. In many expert views, religious moderation is a continuation of the paradigm of the relationship between religions. Compared to before, the government has implemented various forms of policies for managing religious life, including the paradigm of harmony, freedom, and religious moderation [17].

Currently, religious moderation has become part of the mainstream government in its various religious activities. Religious moderation in many places has become the theme of discussions and seminars initiated by the government through the ministry of religion. It is noted that on the Ministry of Religion's Youtube account page, there is a special podcast that contains an edition on religious moderation, such as the Channel of Bimas Islam in collaboration with Muhammadiyah. On many occasions, especially the activity of new student admissions at the Ministry of Religion, religious moderation seems to be a topic that must be conveyed to new students. This certainly invites further important questions about the extent to which the mainstreaming of religious moderation has reached its discourse and echoes to campuses or institutions outside the ministry of religion. It is also interesting to follow up on the role of interfaith religious organizations in responding to this policy of religious moderation at the institutional level in the regions.

\subsection{Configuration of religious moderation between the government and religious organizations}

\subsubsection{Response and understanding of religious moderation}

Religious moderation is not a single concept. Religious moderation has become a concept that develops in every religion as well as in every religious organization. The contested view sees the moderate theme as a theme that is debated by religious groups or scientists so that it is interpreted differently, depending on who and in what context it is understood. According to Ishaq HT, Rais Syuriah Nahdlatul Ulama Jambi: 
"The religious moderation program does not need to be included in the RPJMN. This will lead to something political. Religious moderation would be better if allowed to be socialized slowly with a cultural or cultural approach. Religious moderation has been the substance of the teachings of Nahdlatul Ulama since its establishment. Thus, this matter no longer needs to be regulated in regulations"

However, Ishaq did not refuse if the government had included a religious moderation program in the RPJMN. According to him, the government can play a role in providing reinforcement. Ishaq HT's attitude shows that the conception of religious moderation is not new in the substance of Islamic teachings or organizations. This has been applied and is in line with the practice that has been carried out by Nahdlatul Ulama so far. The attitude of the Jambi Province NU figure is also in line with the views of Arman Syafaat, Deputy Chairman of PW Muhammadiyah Jambi Province. According to him, Muhammadiyah as an Islamic organization views the importance of the religious way of the people which must always be updated according to the current context by referring to the original sources, namely the Koran and the Sunnah. Ustaz Arman Syafaat suggested that the government always socialize religious moderation by always opening up space for discussion and dialogue with religious leaders.

Regarding the response of the Muhammadiyah Jambi mass organization regarding religious moderation in the current government policy, he said:

"The government's challenge in implementing the religious moderation policy is of course not easy because it will be faced with habits that are deeply rooted in society, according to Buya Hamka in his Al Azhar interpretation "Changing one's scientific knowledge will be easy when there is research afterward that is more accurate but changing one's habits will be difficult even though in front of him served as a pile of truth". For this reason, continuous socialization from the government regarding religious moderation is very necessary."

This view of the Muhammadiyah figure in Jambi Province gives the same impression that Muhammadiyah has applied the substance of religious moderation in religious activities such as lectures, da'wah, education, and others, especially among Muhammadiyah.

We also interviewed two representatives of non-Muslim figures about their views on religious Moderation. According to the chairman of the Regional Leadership Council of the Indonesian Christian Intelligence Association, Local Representative of Jambi Province, Dr. Robinson Hutapea says:

"Religious moderation is nothing new. In Christianity, we have the same concept which is Christian moderation. However, the religious moderation referred to by the government has not been properly socialized or it can be said that it has not been effective. Currently, there is no visible seriousness of institutions, both institutions, and institutions including mass organizations, firmly making and socializing the need for these policies and programs."

On the other hand, in the view of Buddhist religious leaders, they give normative answers when asked about religious moderation. Mr. Putu Suratman, who is the head of the Hindu Guidance for the Regional Office of the Jambi Ministry of Religion, said that religious moderation is a very good strategy in fostering togetherness in society. He said that the implementation of religious moderation has been effective in maintaining differences in understanding each other's religious teachings according to their beliefs. $\mathrm{Mr}$. Putu Suratman's view needs to be understood in his context as a government official serving in the ministry of religion. This view shows that there is a belief on the part of the 
government itself that religious moderation promises an effective solution in addressing religious problems in society.

Based on the interviews with religious leaders above, we view that in general religious leaders respond positively to the religious moderation program offered by the government. However, in several respects, the views of these religious leaders indicate that the effectiveness of religious moderation promoted in the RPJMN program has not been properly socialized. In the explanation of the response of religious groups to religious moderation promoted by the government, the response of religious groups is very positive. They welcome the idea of religious moderation as part of what must be implemented in today's community activities. In addition, in the interviews, it was seen that there were no serious enough problems which were considered as the problems of people who have intolerant understandings. Religious groups say that religious moderation is already popular in the everyday language of society. So far, they generally assume that religious organizations have a spirit of religious moderation. This shows that basically, religious moderation is a flexible concept. This seems to be in contrast to some of the facts that show the increasing religious intolerance among the Muslim community today. If it is found that there are several groups of students or students who are intolerant or involved in acts of extremism, this is not sufficient as an accurate picture of the increasing widespread intolerance.

Several indicators of the weakening of religious tolerance among Muslims are something that cannot be denied. As quoted on the PPIM UIN Jakarta page, "many studies confirm that the attitude of openness and respect for differences, including towards minority and marginal groups, our educational actors is still weak (PPIM, 2017, 2018; Wahid Institute, 2019). In the realm of higher education, a number of studies show the spread of extremism among universities/PT (Setara Institute, 2019); the phenomenon of exclusivism in religious education textbooks among public universities (PPIM, 2018); Muslim student activists have religious understandings that tend to be closed (CSRC, 2017); religious activities in the campus environment encourage the growth of exclusive religious views (CISForm, 2018); infiltration of radicalism and extremism in the campus environment through campus mosques (INFID, 2018); and 39\% of students in 7 state universities are exposed to radicalism (BNPT, 2018). [18]" However, the issue of intolerance among religious people has a fairly complex spectrum. In this case, the facts on the ground show that there are still many people who reject Ahmadiyah and Shia as part of Islam. The case of the destruction of the Ahmadiyah mosque in Sintang is proof of how the community still cannot accept the presence of Ahmadiyah in their environment.

\subsubsection{The challenge of religious moderation in educational practices}

In a survey conducted by PPIM in 2020, it was found that many factors of religious moderation are related to pro-violent-extremism opinions, which in other words means that these factors are resilience factors against pro-violent-extremism ideology. Survey stated that "Several factors that are relatively vulnerable and can be strengthened, namely the factor of empathy for adherents of other religions (external empathy), in the form of a relatively low score of perspective-taking ability, and empathy for other sects within Islam (internal empathy), with the score of rejection of adherents of other sects in Islam, is still relatively high. These two factors are the operationalization of tolerance". In response to this, Azyumardi Azra argues that the implementation of moderation has not been maximized in managing religious moderation. Some of the notes given by Azra include the 
ineffectiveness of the religious moderation house program in schools or campuses. For this reason, he suggested that the concept of religious moderation could be applied with an integrative pattern, namely maximizing the functions of institutions on campus such as the Quality Assurance Institute (LPM), Research and Community Service Institute (LPPM), and others. This integrative approach can also be done by including the curriculum of each course [19].

Meanwhile, regarding the application of the value of moderation in schools, we interviewed one of the heads of MAN Insan Cendekia in Jambi Province. According to him,

"Socialization of religious moderation has been quite effective, but it should be underlined that if the program that has been made by the Ministry of Religion is a process that does not take a moment. Internalizing the values of religious moderation is a long process that is not easy. This requires the support of individuals, madrasa residents such as teachers, students, and madrasa families, and the commitment of the community in general. For example, in a boarding school base such as at MAN Insan Cendekia, the implementation of religious moderation must be an integral part of all students' daily activities. In Madrasas, this behavior must be manifested in the classroom as a day-to-day academic and also fostering student integrity in the dormitory".

This suggests that the government only targets government institutions, especially those under the Ministry of Religion. The government has not shown its concern in making religious organizations government agents in the success of religious moderation. Although on many occasions the religious moderation program has embraced organizations at the national level, this has not yet been actualized at the local level. In our observations at higher education institutions in Jambi Province, several non-ministerial religious campuses such as the Jambi Muhammadiyah University Campus and ITS Nahdlatul Ulama Jambi Province have not made religious moderation the theme of the University's welcoming new student event (PBAK). Meanwhile, at state campuses, namely UIN Sulthan Thaha Saifuddin Jambi and Jambi University, religious moderation is a central theme in event of the new students. This is in line with the findings of this study where the religious leaders interviewed said that the socialization of religious moderation had not been effectively carried out by the government. Institutions outside the Ministry of Religion such as public universities and educational institutions under religious organizations which incidentally are outside the Ministry of Religion need more attention.

\section{Conclusion}

This study has found that there is a configuration of religious moderation at the implementation level, indicating that religious moderation must prioritize values that are rooted in the culture and traditions of the community. This needs to be considered by the Ministry of Religion as a leading sector that oversees the successful implementation of religious moderation. We view that the process of implementing religious moderation must reconsider a more accommodating approach to values that have developed in religious organizations or educational institutions. Religious organizations and educational institutions need to be used as government networks to maximize their potential in mainstreaming religious moderation. Indeed, the government cannot impose the ideal concept of religious moderation as it was formulated. However, the government needs to consider the role of religious organizations as 
government partners through their network of educational institutions. Therefore, this research suggested a few things. First, review the roots of the birth of the concept of religious moderation as a political form of religious management. Second, reviewing the concept of religious moderation in its application in religious organizations and examining the influence and response of religious organizations to the idea of religious moderation developed by the government.

\section{References}

[1] Z. Darajat, "Muhammadiyah dan NU: Penjaga Moderatisme Islam di Indonesia," Hayula Indones. J. Multidiscip. Islam. Stud., vol. 1, no. 1, 2017.

[2] M. Hilmy, "Whither indonesia's islamic moderatism? A Reexamination on the Moderate Vision of Muhammadiyah and NU," J. Indones. Islam, vol. 7, no. 1, pp. 24-48, 2013.

[3] A. Syatar, "Strengthening Religious Moderation in University: Initiation to Universitas Islam Negeri Alauddin Makassar," Koriositas, vol. 13, no. 2, 2020.

[4] I. Ropi, “Whither Religious Moderation?,” Stud. Islam., vol. 26, no. 3, p. 598, 2019.

[5] A. N. Burhani, "Al-tawassuṭ wa-1 i "tidāl: The NU and moderatism in Indonesian Islam," Asian J. Soc. Sci., vol. 40, no. 5-6, p. 570, 2012.

[6] H. Nashir, Z. Qodir, A. Nurmandi, H. Jubba, and M. Hidayati, "Muhammadiyah's Moderation Stance in the 2019 General Election: Critical Views from Within.," Al-Jami'ah J. Islam. Stud., vol. 57, no. $1,2019$.

[7] H. Nashir, "Moderasi Indonesia dan Keindonesiaan," 2020.

[8] P. P. Muhammadiyah, Indonesia Berkemajuan: Rekonstruksi Kehidupan Kebangsaan yang Bermakna. Yogyakarta: Pusat Pimpinan Muhammadiyah, 2015.

[9] A. Azra, Indonesia, Islam, and democracy: Dynamics in a global context. Equinox Publishing, 2006.

[10] M. Ali, Reinvensi Pendidikan Muhammadiyah. Al-Wasat Publishing House, 2010.

[11] T. Suharto, "Gagasan Pendidikan Muhamadiyah dan NU sebagai Potret Pendidikan Islam Moderat di Indonesia," Islam. J. Stud. Keislam., vol. 9, no. 1, p. 83, 2014.

[12] A. Azra, "No Title." https://jibpost.id/muhammadiyah-dan-moderasi-beragama-perspektif-islamberkemajuan/ .

[13] Team of Authors of Ministry of Religious Affairs, Moderasi Beragama. Jakarta: Balitbang Kementerian Agama RI, 2019.

[14] M. Van Bruinessen, "Introduction: Contemporary Developments in Indonesian Islam and the "Conservative Turn," in Contemporary Developments in Indonesian Islam, ISEAS Publishing, 2013, pp. 1-20.

[15] A. Feillard, R. Madinier, and W. Wong, The end of innocence: Indonesian Islam and the temptations of radicalism. Honolulu: University of Hawai'i Press, 2011.

[16] "No Title." https://kemenag.go.id/read/gebrakan-gus-yaqut-untuk-kemenag-baru-kde76.

[17] Z. A. Bagir, H. Mubarok, and I. Rafsadi, "Arena dan Paradigma," in Kerangka Hukum dan Kelembagaan Tata Kelola Kehidupan Keagamaan di Indonesia, .

[18] “No Title.” https://ppim.uinjkt.ac.id/2021/03/01/rilis-temuan-survei-ppim-paparkan-potrettoleransi-beragama-di-universitas/.

[19] R. to R. R. L. Azyumardi Azra, "Potret Moderasi Beragama di Kalangan Mahasiswa Muslim." https://www.youtube.com/watch?v=Fx5itp2ZGYc\&list=PLtpwAkCnhJt3SWBcIvpUd7N5sRQtTfpd c\&index $=44$ (accessed Feb. 25, 2021). 
